\title{
PROJECTION OF WATER UTILITIES FOR CUSTOMERS IN EAST TIMOR - LESTE IN DILI FOR SUSTANAIBLE DEVELOPMENT GOALS (SDGs) 2030
}

\author{
Geazi Isai Reis dos Santos \\ Department of Civil Engineering, University of Narotama, Surabaya \\ Adress Arief Rachman Hakim 51, 60117 \\ geazireissantos11@gmail.com \\ F. Rooslan Edy Santosa \\ Department of Civil Engineering, University of Narotama, Surabaya \\ Rooslan.edy@gmail.com
}

\begin{abstract}
Water in human life has a very vital function. The daily activities of humans never escape from water. Starting from bathing, washing, cooking up to the elements of human body One is also composed of water. To obtain the projected results of population growth for the next 10 years, the calculation of water discharge in Dili City. Population projections with geometric methods use the assumption that the number of people will increase geometric. The rate of growth is considered the same for each year. Of the increase of population in the year 2017 population growth in Dili by $12.8 \%$ with a population of 234,062 , used as a reference for the projected population for the next 10 years (2017-2027). Based on the increase of population used is $12.8 \%$ and the population is 10 years (2018-2027) for 2.395.75 inhabitants. The balance of clean water needs in urban clean water services.

Keywords : Water supply, SDGs 2030, Geometric Projection, Population Growth, Dili City Timor - Leste.
\end{abstract}

\section{INTRODUCTION}

\section{Background}

Water in human life has a very vital function. The daily activities of mankind never escape from water. Starting from bathing, washing, cooking up to the elements of human body one of them also consist of water. Therefore, clean water that does not contain chemical elements that harm and impair the functioning of the human body is indispensable.

At this time, the growth of the people of Timor-Leste has reached a considerable number. As the population grows, the amount of life needs to be fulfilled is also greater. One of the main necessities of life is the need for clean water.

The problem of water supply is now a special concern for developed countries and emerging economies. Timor-Leste as one of the developing countries, is not separated from the problem of providing clean water to its people. One of the main problems faced is the lack of the availability of clean water, not in fact the provision of clean water services especially in rural areas and clean water sources that have not been utilized to the fullest. In large cities clean water resources utilized by the PDAM city of Dili known by the people of Timor-Leste 
Volume 03 Number 01 September 2019

(Direcao Nacional de Servico de Aqua) has been buried by domestic waste of industrial and waste, so the burden of clean water management is increasingly Increased.

\section{Research Objectives}

Obtaining the results of population growth projection calculation for the next 10 years. Obtain the calculation of water discharge in Dili City for 10 forwards.

\section{Water Discharge}

Water discharge is a reliable discharge for a particular probability. Probabiltas for this flagship debit is different. For the purposes of irrigation commonly used probability $80 \%$. For the purposes of drink water and industry of course demanded higher probability, which is $90 \%$ up to $95 \%$ (Soemarto, 1987). The greater the percentage of its flagship value indicates also the initial priority to get water. Thus, the mainstay can also be called as minimum discharge at a certain level of opportunity that can be used for water supply. So this mainstay of discharge is necessary to calculate the discharge from water source reliable for a particular purpose.

\section{Water availability.}

Water availability is assumed by the provision of water Din River, although in the assessment of irrigation, effective rain is also included in water availability. The main concern in water availability is on streams, but with some rain considerations included. The factors influencing the use of water, among others (Linsley, Joseph, Sasangko, Djoko,1986).

- Climate

- Population characteristics

- Environmental issues

- Industry and Merchandising

- Water Dues and metered

- City size

- The need for water Consrvasi

\section{Sanitation and Sustainable Development Goals (SDGs)}

Sanitation and Sustanaible Development Goals (SDGs). This Agenda is considered important considering that the moment of sustainable development becomes a challenge, the survival of people in various places threatened and biodegradable no longer support. At the same time had challenges in development, as well as the previous MDGs. To face the greatest challenge is required an effective agenda, the human and Earth's humanity.

The water supply is still a problem in the city. The availability of clean water is not evenly distributed in the city so that the goal of fulfillment of sustainable Development Goals (SDGs) 2030.

\section{Total population projection growth}


Population growth rate The projected population is to determine the approximate number of people in the years to come according to the desired planning period.Below are the methods used in the calculation of population:

\section{Geometric methode}

Population projections with geometric methods use the assumption that the number of people will increase in geometric. The rate of growth is considered the same for each year. Here's the formula used in the geometric method:

$$
\begin{array}{ll}
\mathrm{Pn} & =\mathrm{Po} \times(1+r)^{\mathrm{n}}(2.1) \text { and }: \ldots \ldots \ldots \\
\mathrm{Pn} & =\text { Population in the year }(\mathrm{n}) \\
\mathrm{Po} & =\text { Population in the base year } \\
\mathrm{R} & =\text { Population growth rate } \\
\mathrm{N} & =\text { Number of intervals }
\end{array}
$$

\section{Hydraulics analysis in clean water network system}

\section{a. Law of Bernouli}

The water inside the pipes always flows from a place that has a higher energy place leading to a place that has a smaller energy height. The flow has three kinds of energy working in it, namely:

$>$ Energy altitude $=\mathrm{h}$, with :

$\mathrm{h}=$ The height of the point from the reference line reviewed $(m)$.

$>$ Speed energy $=\frac{v^{2}}{2 g}$, with :

$\mathrm{v}=$ Speed $(\mathrm{m} / \mathrm{det})$

$\mathrm{g}=$ Gravity acceleration $\left(\mathrm{m}^{2} / \mathrm{det}\right)$

$>$ Energi tekanan $=\frac{p}{y w}$, with:

$\mathrm{p}=$ Pressure $(\mathrm{kg} / \mathrm{m} 2)$

$\mathrm{yw}=$ Heavy water $(\mathrm{kg} / \mathrm{m} 3)$

The principle of Bernouli explains that total energy in a cross section of pipes is the amount of energy velocity, energy pressure and energy that can be written as follows:

$$
\mathrm{E}_{\mathrm{Tot}} \quad=\text { Energy altitude }+ \text { Energy pressure }=\mathrm{h}+\frac{v^{2}}{2 g}+\frac{p}{y w}
$$

According to the energy Eternity Theory of the law of Bernouli i.e. when no energy escapes or is received between two points in a closed system,

$$
\mathrm{h}+\frac{v^{2}}{2 g}+\frac{p}{y w}
$$

According to the eternity of energy from the laws of Bernouli i.e. when no energy escapes or is received between two points in a closed system, the total energy remains constant. 
The Law of Eternity in the picture above is written as follows (Haestad, 2002: 267):

$\mathrm{Z}+\frac{P_{1}}{y w}+\frac{v_{1}^{2}}{2 g}=\frac{p_{2}}{y w}+\frac{V_{2}^{2}}{2 g}+h_{l}$

\section{Research flowchart}

\section{FLOW CHART}

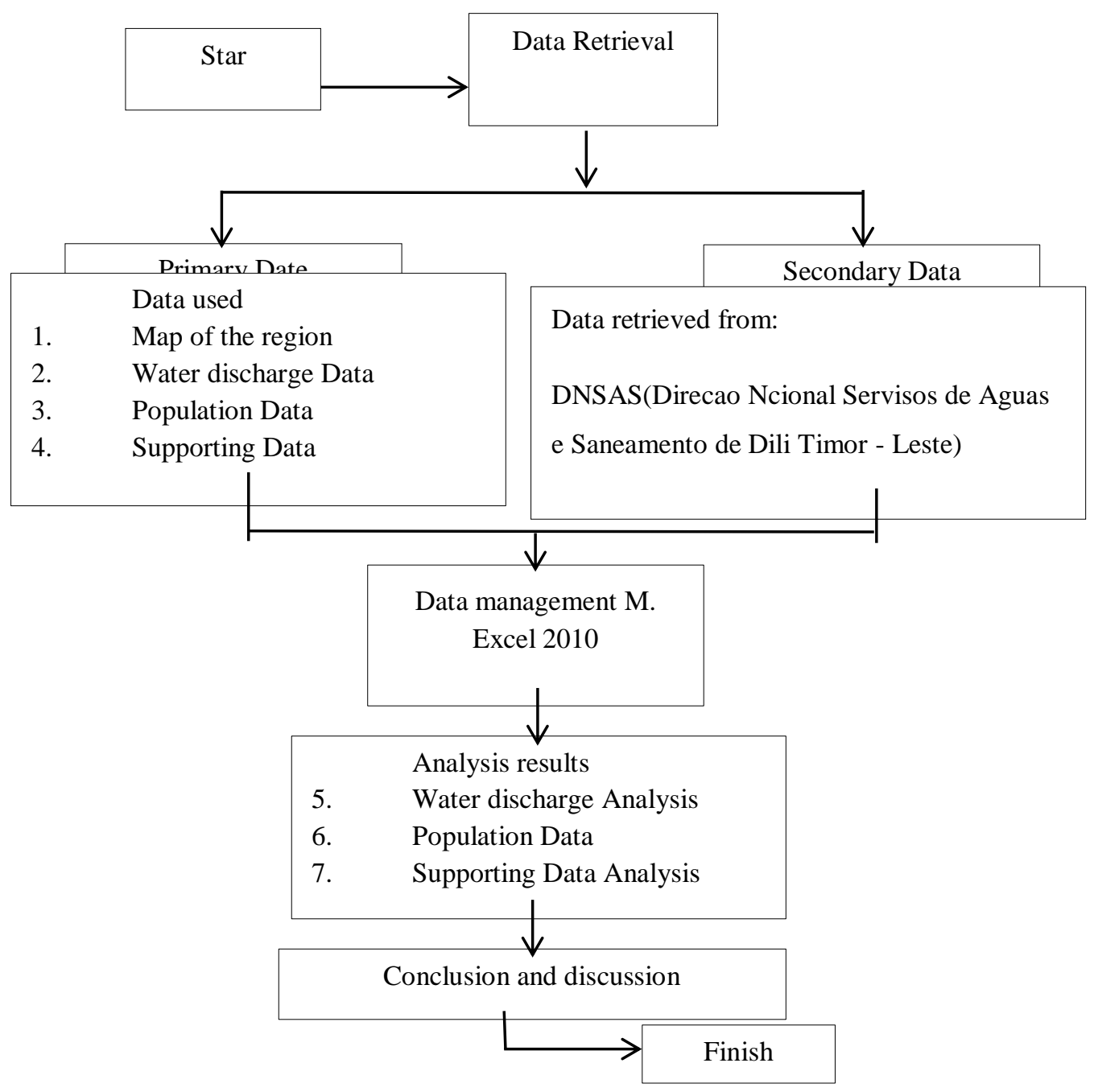

RESULT AND DISCUSSION

\section{Overview}

The research was conducted in Dili City where the largest city in Timor-Lese and is the capital of East Timor. The majority of the city of Dili have an espesial language of TETUN and Portuguis, with the extent of Dili is $48.27 \mathrm{~km} 2$ the majority of inhabitants in Dili city of Bergama Catholics. And the Catholic Church is the dominant religious institution. There are also a small portion of the Protestant and Muslin community, (Catholic 90\% Protestant 5\% Muslim 5\%). Based on data 
obtained from the central DNSAS office of the Dili capital of Timor-Leste in 2017 population in Dili city of 234.062 inhabitants. To fulfill the needs of clean water of Dili city people rely on clean water supply of PDAM Center in Dili City. And many people who still use water wells or water pumps in the year 2017 number of customers who use water supply coming from the center of Dili City PDAM as much as 1,437 customers.

\section{Population increase in Dili city}

The population is changing the number of people in a specific region each year. The usefulness of the increase is to predict the number of people in the upcoming region. Resident Data is required for development planning purposes because the population is an aspect of development and aspects of population growth. The population growth of each region is influenced by some factors including birth. From the population growth of 2017 in Dili, $12.8 \%$ with a population of 234,062 , it was used as a reference for the projected population for the next 10 years (2017 2027). To perform the projection of the population in Dili, this method uses geometric methods, which use the assumption that the population will be geometric plus each year and rate of growth.

Table 1. Population and number of years $(2017-2027)$

\begin{tabular}{llll}
\hline No & Years $(\mathrm{n})$ & $\begin{array}{l}\text { Population increase } \\
(\mathrm{r})\end{array}$ & $\begin{array}{l}\text { Population } \\
\mathrm{P}=\mathrm{Po}(1+\mathrm{r})^{2}\end{array}$ \\
\hline 0 & 2017 & $12,8 \%$ & 234,62 \\
1 & 2018 & $12,8 \%$ & 29430 \\
2 & 2019 & $12,8 \%$ & 36916 \\
3 & 2020 & $12,8 \%$ & 47309 \\
4 & 2021 & $12,8 \%$ & 58090 \\
5 & 2022 & $12,8 \%$ & 72869 \\
6 & 2023 & $12,8 \%$ & 91406 \\
7 & 2024 & $12,8 \%$ & 1.163 .03 \\
8 & 2025 & $12,8 \%$ & 1.479 .82 \\
9 & 2026 & $12,8 \%$ & 1.882 .89 \\
10 & 2027 & $12,8 \%$ & 2.395 .75 \\
\hline
\end{tabular}

According to Table 1. The population is known to be added at $12.8 \%$ and the population is for 10 years $2018-2027$ of 2.395 .75 inhabitants.

\section{Clean water needs balance.}

Clean water balance in the urban area Clean water service is done to adjust the level of demand for clean water with the supply of clean water. The adjustments 
are influenced by three factors, namely the level of consumption of people per day, the level of service of water supply, and service to the use of industrial land. Taking into consideration these three factors, the form of clean water is obtained with clean water consumption of 120 liters/person/day. The use of clean water becomes one of the responsibilities of services that must be provided.

Table 2. Clean water needs balance

\begin{tabular}{|c|c|c|c|c|c|c|c|c|c|c|}
\hline A Years & 2018 & 2019 & 2020 & 2021 & 2022 & 2023 & 2024 & 2025 & 2026 & 2027 \\
\hline \multicolumn{11}{|l|}{ B Availabi } \\
\hline $\begin{array}{l}\text { lity } \\
\text { Water } \\
(\mathrm{l} / \mathrm{s})\end{array}$ & 70 & 70 & 70 & 70 & 70 & 70 & 70 & 70 & 70 & 70 \\
\hline \multicolumn{11}{|l|}{ C Water } \\
\hline supplie & 8.53 & 8.75 & 8.97 & 9.19 & 9.53 & 9.74 & 9.95 & 10.11 & 10.52 & 10.73 \\
\hline $\begin{array}{l}\text { s (F- } \\
1.15)\end{array}$ & 4 & 9 & 9 & 3 & 9 & 9 & 6 & 0 & 0 & 0 \\
\hline $\begin{array}{l}\text { D Shortag } \\
\text { e of }\end{array}$ & - & - & - & - & - & - & - & - & - & - \\
\hline $\begin{array}{l}\text { product } \\
\text { ion } \\
\text { (l/det) }\end{array}$ & $\begin{array}{l}8.46 \\
4\end{array}$ & $\begin{array}{l}8.75 \\
9\end{array}$ & $\begin{array}{l}8.90 \\
9\end{array}$ & $\begin{array}{l}9.12 \\
3\end{array}$ & $\begin{array}{l}9.46 \\
9\end{array}$ & $\begin{array}{l}9.67 \\
9\end{array}$ & $\begin{array}{l}9.88 \\
6\end{array}$ & $\begin{array}{l}10.04 \\
0\end{array}$ & $\begin{array}{l}10.45 \\
0\end{array}$ & $\begin{array}{l}10.66 \\
0\end{array}$ \\
\hline
\end{tabular}

Description : $\{\mathrm{A}\}=$ Projection Years

$\{B\}=$ Water Supply

$\{C\}=$ Total water needs

$\{D\}=\{B\}-\{C\}$

Thus, the difference in the balance between supply and demand is that occurred in the year 2018-2027 of-10,660 (Lt/sec). Thus the provision of clean water needs in Dili City is still less fulfilled. Because the difference in value between the total Supply and Demand is influenced by several things, among them there is still a group of people who still use the well and still a group of people who lack understanding of the importance of clean water is reviewed from the quality and ease of subscription.

\section{CONCLUSION}

At this time, the growth of the people of Timor-Leste has reached a considerable number. As the population grows, the amount of life needs to be fulfilled is also greater. One of the main necessities of life is the need for clean water. The increase in population used is $12.8 \%$ and the population is for 10 years $2018-2027$ for 2.395.75 inhabitant.

\section{REFERENCES}

Afrianto, L., Rohmat, D., \& Jupri. (2015). Projection of clean water needs in Indramayu sub-district to the year 2035. Geographical Anthology, 3, 1- 12.

Decree of the Minister of Health of Republic of Indonesia number 416/Mengkes/PER/IX/1990. Terms and supervision of clean water quality, Jakarta Klas, Dua, K.S.Y., (2009), pipe network design, Bandung 
Eriyanto.(2018). "PROJECTION NEEDS WATER UTILITIES FOR CUSTOMERS IN WEST SURABAYA ZONE 4". Faculty of Civil Engineering. Narotama University Surabaya.

Google Map 2017 , Peta wilayah di kota Dili Timor - Leste https://www.google.com/maps/place/D\%C3\%ADli,+Timor-Leste/@$8.5564142,125.5348888,12345 \mathrm{~m} / \mathrm{data}=! 3 \mathrm{~m} 1 ! 1 \mathrm{e} 3 ! 4 \mathrm{~m} 5 ! 3 \mathrm{~m} 4 ! 1 \mathrm{~s} 0 \times 2 \mathrm{~d} 01 \mathrm{e} 70$ d32288115:0x3d9d6ee9546912d9!8m2!3d-8.5568557!4d125.5603143/

Ishartono dan Raharjo ,santoso Tri.2015.Sustainable Development Goals (SDGs) Dan Pengetasan Kemeskinan Bandung

Linsley, R.K,Franzini,Joseph,B.F.Sasangko,Djoko,1986,T Water resource Eknik, Volume 2 third edition, Eirlangga, Jakarta.

Nohanamian Tambun 2014, Report on the FLAGSHIP DISCHARGE CALCULATION AS A source of WATER resources JAYAPURA

North Of Surabaya City According To SDG's. International Journal of Transportation and Infrastructure (IJTI). Vol. No. 1. September, 2018. Page : 39-46.

PPJSR,2015, map of the Territory division of the subscription, solar PDAM Sembada Kota Surabaya.

Reynolds, 1996. Unit Operations and Progress in Enviromental Engineering, PWS Publishing Company,Boston

Rumpuin, A.F and Santosa, F.R.E (2018). Analysis Of Clean Water Achievements In The

Santosa, F.R.E and Hermana, J (2012). Mapping of Environmental Health Risk Area for Surabaya City as an Evaluation of Millenium Development Goals 2015. International Journal of Academic Research (IJAR). Vol. 4. No. 1. January, 2012, page: 168-172.

Santosa, F.R.E, Arimbawa, I.G, and Nasihien, R.D (2019). Environmental Health Risk Assessment (EHRA) to Achieve the Target of Universal Access 2020 on Domestic Waste Water Sector in Blitar Districts. International Journal Of Integrated Engineering (IJIE) Vol 11 No 9 (2019) 132-140.

Sari, T. (2017). CLEAN WATER FOR PRACIMANTORO SUBDISTRICT SERVED BY GIRI PRACIMANTORO PDAM SERVED BY GIRI.

Yuliana Rivai 2001, Final task Report on EVALUATION OF DISTRIBUTION SYSTEM AND PLAN to IMPROVE WATER SERVICE in GORONTALO CITY. 